Dhaka Univ. J. Biol. Sci. 21(2): 141-152, 2012 (July)

\title{
PRODUCTION PERFORMANCE OF CLOSED WATER FISHERY RESOURCES IN NARAYANGONJ-NARSINGDI IRRIGATION PROJECT
}

\author{
Md. Motaher Hossain, Mohammed Shafi ${ }^{1}$ And Md. Kawser Ahmed ${ }^{1 *}$ \\ Department of Fisheries, Matshya Bhaban, Ramna, Dhaka-1000, Bangladesh
}

Key words: Ponds and borrow pits, Narayangonj-Narsingdi Irrigation Project

\begin{abstract}
A survey was conducted both inside (flood-free zone and flooded zone) and outside the embankment of Narayangonj-Narsingdi Irrigation Project, Rupgonj, Narayanganj. All ponds and borrow pits were surveyed from the randomly $10 \%$ selected villages by using pre-tested questionnaires. The highest production was in semi-intensive ponds $(3,827$ and $3,979 \mathrm{~kg} / \mathrm{ha})$ in flood-free zone, $(3,911$ and $4,000 \mathrm{~kg} / \mathrm{ha})$ in flooded zone and $(3,800$ and $4,000 \mathrm{~kg} / \mathrm{ha})$ in outside zone, while, the lowest production was found $(1,756$ and $1,759 \mathrm{~kg} / \mathrm{ha})$ in flood-free zone, $(1,603$ and 1,646 kg/ha) in flooded zone and $(1,699$ and 1,706 kg/ha) in outside zone in 2003-2004 and 2004-2005, respectively. It was also observed that the production of culturable ponds was higher (959 and $942 \mathrm{~kg} / \mathrm{ha}$ ) in outside, followed by flooded zone (950 and $917 \mathrm{~kg} / \mathrm{ha}$ ) and the lowest production in flood-free zone (400 and $356 \mathrm{~kg} / \mathrm{ha}$ ) in 2003-2004 and 2004-2005. The highest average production of fishes in closed water (ponds and borrow pits) was found in flood-free zone $(23,277$ and $2,368 \mathrm{~kg} / \mathrm{ha})$, followed by flooded zone $(2,249$ and $2,336 \mathrm{~kg} / \mathrm{ha}$ ) and the lowest average production in outside zone (1,972 and 1,985 $\mathrm{kg} / \mathrm{ha}$ ) in 2003-2004 and 2004-2005, respectively. The higher significant difference $(\mathrm{p}<0.001)$ was found between the production of flood-free zone and outside zone in both 2003-2004 and 2004-2005, where no significant difference ( $p>0.05)$ was found between the production of flooded zone and outside zone both in both years.
\end{abstract}

\section{Introduction}

In Bangladesh, culture based fishery is a suitable option of fish culture in closed water bodies mainly ponds and borrow pits. After the construction of Flood Control, Drainage and Irrigation Projects (FCDI), the culture fishery has been developed in the project areas. Fish production has been increased to 21.02 lakh $\mathrm{mt}$ in 2003 - 2004, which was 17.81 lakh $\mathrm{mt}$ in 2000-2001(1). In Bangladesh, fish provides up to $63 \%$ of animal protein consumed ${ }^{(1,2)}$. More than $80 \%$ of the animal protein in the diet come from fisheries products alone ${ }^{(3)}$. Most of the people in developing world are still dependent almost entirely on fish as a source of animal protein. Fish protein is $85-95 \%$ digestible and all dietary essential amino acids are present in fish ${ }^{(4)}$.

*Author for correspondence: <kawser@univdhaka.edu>. 1Department of Fisheries, University of Dhaka, Dhaka-1000, Bangladesh. 
Although after construction of embankment inland open water fisheries decreased but pond production has increased. According to BFRSS(5) Bangladesh has 1,288,222 manmade ponds which provide a total area of 146,890 ha. Now-a-days, some borrow pits and ditches have been developed. According to ${ }^{(6)}$ on the impact of flood control in three FCDI projects it was found that flood protection improved conditions for expanding and intensifying pond fish culture.

At national level, $46 \%$ of the ponds (covering 52\%) are under aquaculture. The remaining ponds are either culturable or derelicts ${ }^{(5)}$. The area of derelict, cultured and culturable ponds were estimated to be about 43,27 and $30 \%$, respectively(7), but according to ${ }^{(8,9)}$ are 12,65 and $23 \%$, respectively. In the year 1987-88, total inland culture production was 1.76 tons but in 2004-2005, the total inland culture production was 8.82 $\mathrm{mt}$ of which only pond production was $7.57 \mathrm{mt}^{(8,9)}$. Before the flood control and irrigation projects were implemented, production of fishponds in flood-prone areas was very low. Aquaculture was risky because there was possibility of inundation. Once flood control infrastructure was built, this risk greatly diminished. According to recent statistics, i.e., $(8,9)$ on an average 2,482 kg/ha of fish are produced in ponds of Bangladesh.

\section{Materials and Methods}

Closed water (ponds and borrow pits) survey was carried out. Ponds and borrow pits were surveyed in both inside and outside of the embankment. At first $10 \%$, out of 89 villages was selected randomly from inside the embankment of the flood-free zone. Similarly $10 \%$, out of 35 villages was selected randomly from inside the regulator of the flooded zone. Then all the ponds and borrow pits of the selected villages were surveyed from both flood-free zone and flooded zone. The selected nine villages covered five unions inside the embankment of flood-free zone and four villages covered two unions inside the regulator of the flooded zone of the project area. Thus 64 ponds and two borrow pits from flood-free zone and only 26 ponds from flooded zone were surveyed by using the pre-tested questionnaires which included questions like fish production, types of fish species, types of culture, ownership, position of pond owners, methods of fish culture, problems of fish culture etc. Similarly, the same methods were applied in outside the embankment and 16 villages out of 161 were selected randomly. So, the selected $10 \%$ villages include only 81 ponds and borrow pits which were surveyed and the data as in inside were collected. The surveys were conducted for the period of two years (2003-2004 and 2004-2005).

As the numbers of ponds and borrow pits between inside and outside zones of NNIP were unequal, so independent $t$-test is done for significant test. It was observed that there was a difference between the average production of fish $(\mathrm{kg} / \mathrm{ha})$ of inside (flood-free zone and flooded zone) and outside closed water bodies of NNIP at Rupgonj area during both the years of study. When the difference is statistically tested between the inside (flood- 
free zone) and outsides ponds and borrow-pits fish production it was observed that the difference in closed water (ponds and borrow-pits) fish production between the two zones was significant at 0.001 level $(p=0.001)$. And when the difference was statistically tested between the inside (flooded zone) and outside ponds and borrow pits fish production was insignificant at 0.05 level $(p=0.539$ and 0.724$)$.

\section{Results and Discussion}

In NNIP area, closed water fisheries based on culture fisheries in the ponds and borrow-pits have been developed after construction of embankment. Particularly, the development of culture fisheries was noticed in the ponds and borrow-pits in flood-free zone. The findings was recorded in terms of flooding, type of water body, ownership, type of culture, method of culture, problems of fish culture regarding the production of culture fishery resources both inside and outside of NNIP in Rupganj area.

In 2003-2004, it was observed that only $7.58 \%$ ponds and borrow pits were over flooded in inside (flood-free zone) the embankment causing rain water congestion which was $9.09 \%$ in 2004-2005. In case of flooded zone in inside the embankment/regulator $53.85 \%$ were over flooded in monsoon, and $61.54 \%$ in 2004-2005. On the other hand, in outside region, 54.32 and $56.79 \%$ in 2003-2004 and 2004-2005, respectively were subjected to over-flooding during monsoon. It was observed that $8-9 \%$ ponds and borrow pits were over-flooded in flood free zone in inside due to rain water congestion, where 54-62\% were over flooded in the flooded zone and $54-57 \%$ were over flooded in outside the
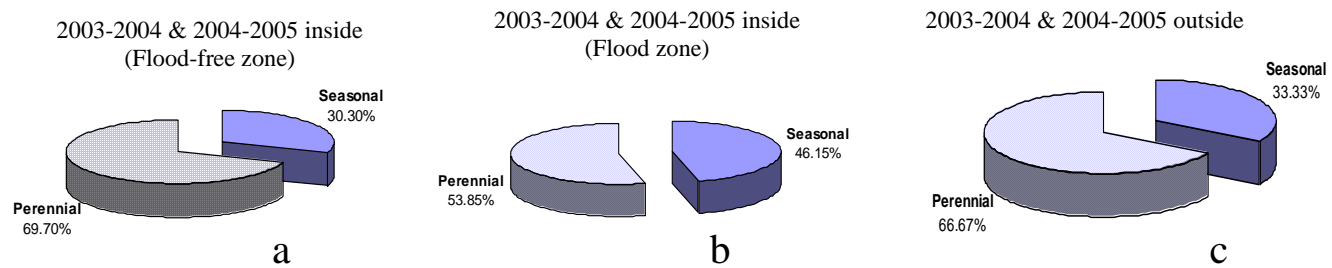

Fig.1 (a-c). Contribution of ponds and borrow-pits on the basis of type of water body both inside and outside the NNIP in 2003-2004 and 2004-2005.

embankment during monsoon. Although no exact work was done like inside and outside area of the embankment but ${ }^{(10)}$ reported that $53.3 \%$ ponds were found to become flooded every year, which was almost similar with the present findings in flooded zone and outside the embankment.

Among the surveyed ponds and borrow pits $30.30 \%$ were seasonal and $69.70 \%$ were perennial in inside the embankment (flood-free zone) of NNIP in both years of study. In case of flooded zone, mainly $46.15 \%$ ponds were seasonal and $53.85 \%$ perennial. Whereas, in outside the embankment $33.33 \%$ were seasonal and $66.67 \%$ perennial in both years of study (Fig. 1a-c). 
It was observed that $25.76 \%$ were single in inside the embankment (flood- free zone), $26.92 \%$ in inside the embankment (flooded zone) and 30.86\% in outside in two years of study. But $25.76 \%$ were joint ownership in inside the embankment in two years of study and only different result in case of flooded zone in inside was $42.31 \%$ in $2003-2004$ and $46.16 \%$ in 2004-2005. The same result (40.74\%) was in outside in 2003-2004 and 2004-2005. In case of lease ownership, $48.48 \%$ were in flood-free zone and $28.40 \%$ in outside region in both years of study which were $30.77 \%$ in $2003-2004$ and $26.92 \%$ in $2004-2005$ in case of flooded zone in inside the regulator. These results are represented in Fig. 2.

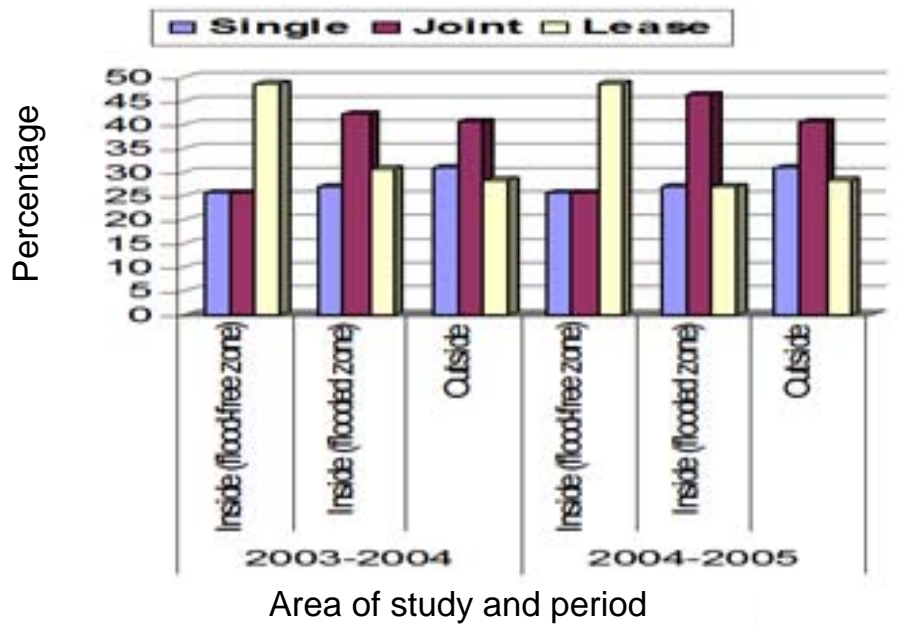

Fig. 2. Contribution of ponds and borrow-pits on the basis of ownership both inside and outside of NNIP in 2003-2004 and 2004-2005.

Considering the ownership, it was found that the single ownership $(25.76 \%)$ in floodfree zone and $26.92 \%$ in flooded zone in inside was less than outside $(30.86 \%)$, where the joint ownership in flood-free zone $(25.76 \%)$ was less than outside $(40.74 \%)$. But compared to outside the joint ownership is higher in flooded zone $(42.31 \%)$. On the other hand, lease ownership (48.48\%) in flood-free zone and 30.77\% in flooded zone in inside are less than that of outside $(28.40 \%)$. Joint ownership was very high in flooded zone and outside zone in compared to flood-free zone. So, the results of flooded and outside zone are in conformity with the findings of ${ }^{(11),(12)}$ and ${ }^{(10)}$. But they did not find the lease ownerships. The present findings indicated that the remarkable number was found as lease ownerships in case of both inside and outside, which differs with the above mentioned findings ${ }^{(10)}$ also noticed that multiple ownership is an important problem, which is also found in the present investigation. Moreover, BRAC ${ }^{(13)}$ also expressed the same opinion.

In Rupgonj area of NNIP, two types of ponds (cultured and culturable) were found both in inside and outside the embankment. But no borrow-pits were found as 
culturable. In flood-free zone of inside the embankment, $95.45 \%$ ponds and borrow pits were cultured and 4.55\% was culturable in 2003-2004 and 2004-2005 and in case of flooded zone of inside the embankment $84.62 \%$ were cultured and $15.38 \%$ were culturable in both the years of study. But in outside region, 80.25 and $81.48 \%$ were cultured, whereas, 19.75 and $18.52 \%$ were culturable in both the years of study (Fig. 3a-d).

It obviously indicates that the opportunities of fish culture in ponds and borrow pits is very high and occurred for the construction of embankment. In all cases the number of cultured ponds are very high, which does not support the reports of SPARRSO(7). Haque $^{(14)}$ that only $43 \%$ of the total pond area of Bangladesh were under fish cultivation. The present findings show that $80 \%$ and above were cultured ponds both in inside and outside.

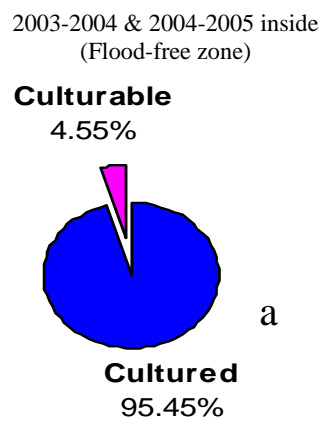

2003-2004 outside

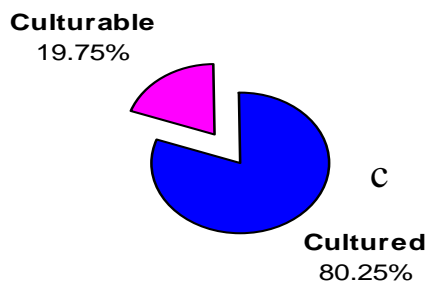

2003-2004 \& 2004-2005 inside (Flood zone)

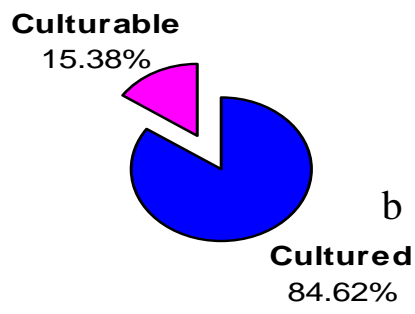

2004-2005 outside

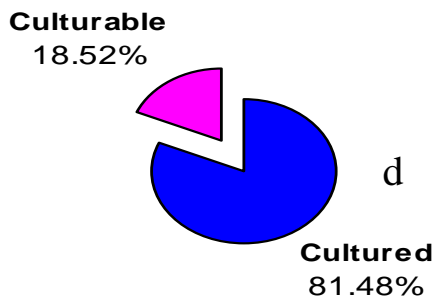

Fig. 3(a-d). Contribution of ponds and borrow-pits on the basis of type of culture both inside and outside of NNIP in 2003-2004 and 2004-2005.

Extensive and improved extensive methods of fish culture were most commonly followed in both inside and outside regions of NNIP. In inside the embankment (floodfree zone), extensive $(42.86 \%)$ and improved extensive $(50.79 \%)$ and semi intensive (6.35\%) were observed in 2003-2004 and 2004-2005. But in case of flooded zone, 63.63\% were extensive, $31.82 \%$ were improved extensive and $4.55 \%$ were semi-intensive in 20032004. Almost similar result was found $(59.09,36.36$ and 4.55\%) in 2004-2005. On the other hand, in outside region, 50.77, 47.69 and $1.54 \%$ practiced extensive fish culture, improved 
extensive and semi intensive fish culture, respectively in $2003-2004$, and $51.51 \%$ extensive method of fish culture, $46.97 \%$ improved extensive and $1.52 \%$ semi intensive fish culture in 2004-2005 (Fig. 4).

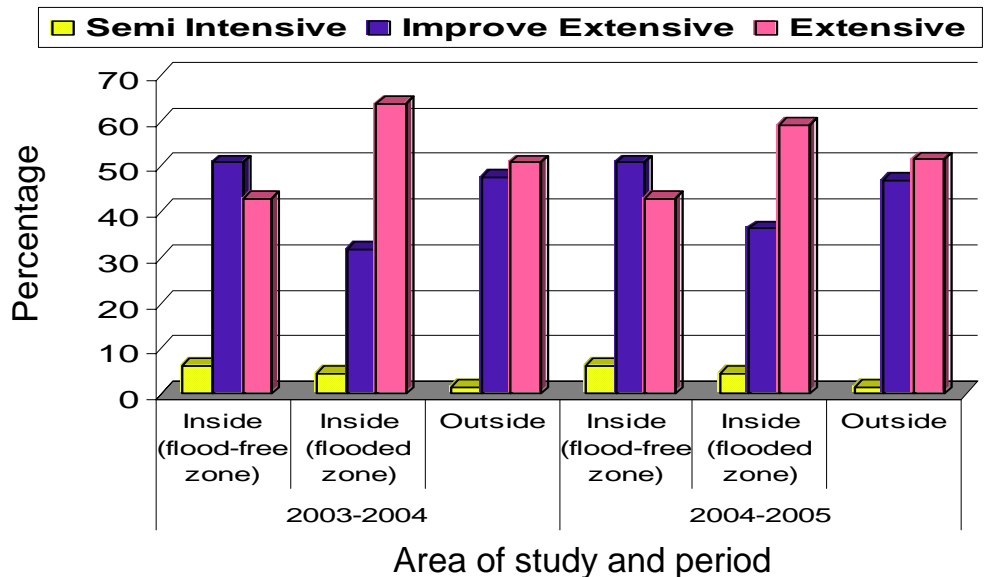

Fig. 4. Contribution of ponds and borrow-pits on the basis of method of culture both inside and outside of NNIP in 2003-2004 and 2004-2005.

The result showed that $42.86 \%$ were extensive, 50.79\% improved extensive and $6.35 \%$ semi-intensive in flood-free zone in inside, whereas, $63.63 \%$ were extensive, $31.82 \%$ improved extensive and $4.55 \%$ semi-intensive in flooded zone in inside; but $50.77 \%$ extensive, $47.69 \%$ improved extensive and $1.54 \%$ semi-intensive method was followed in outside region. It is clear that culture technology has been more developed in flood-free zone than flooded zone and outside.

The views of the surveyed ponds and borrow pit owners in inside and outside region of NNIP regarding problems associated with fish culture in their ponds and borrow pits are presented in Fig. 5. The principal problem was lack of fund (36.36 and 37.88\%) in inside the embankment (flood-free zone), but in case of flooded zone, the main problem was lack of training (34.62\%), whereas, in outside region, it was lack of training (37.04 and $38.27 \%$ ) in 2003-2004 and 2004-2005, respectively. The second main problem was lack of training $(27.17 \%)$ followed by lack of unity $(24.24 \%)$ in flood-free zone in 2003-2004. On the other hand, it was lack of unity $(27.17 \%)$, followed by lack of training (24.24\%) in the same zone in 2004-2005. The lowest was prevention of disease (4.55 and 3.03\%) in both years. In case of flooded zone, the second highest was lack of fund (23.08\%), followed by inundation in monsoon (15.38\%) and lack of unity $(11.54 \%)$ and the lowest was prevention of disease and non-availability of fry (7.69\%) in 2003-2004. The second highest was lack of fund (26.92\%), followed by lack of unity $(15.38 \%)$ and inundation in 
monsoon (11.54\%), but the lowest was prevention of disease (3.85\%) in 2004-2005. In outside region, the second highest problem was lack of fund $(24.69 \%)$, followed by inundation in monsoon $(19.75 \%)$ and lack of unity $(7.41 \%)$, the lowest was prevention of disease $(4.94 \%)$ in $2003-2004$. The second highest was lack of fund $(25.93 \%)$, followed by inundation in monsoon $(20.99 \%)$ and lack of unity $(6.17 \%)$, whereas the lowest was prevention of disease $(3.70 \%)$ in 2004-2005. In both years, there was no inundation in monsoon in flood-free zone of inside the embankment.

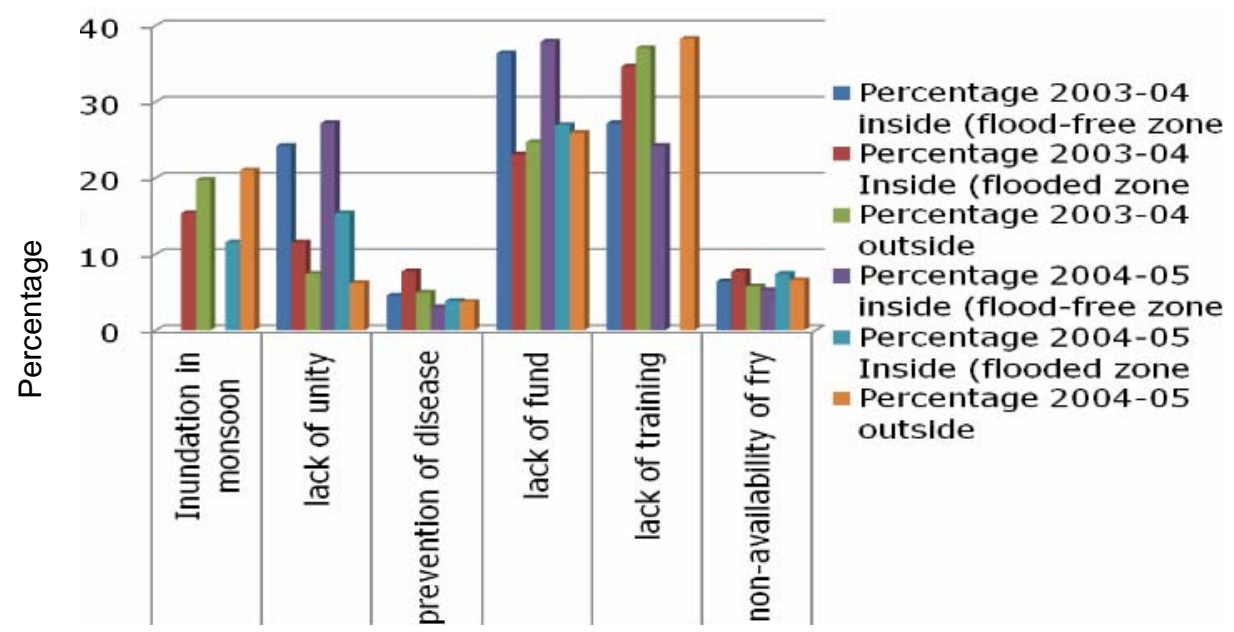

Fig. 5. Problems of fish culture in ponds and borrow-pits both inside and outside of NNIP in 20032004 and 2004-2005.

Kaiya et al. ${ }^{(10)}$ noticed that multiple ownership as an important problem, which is also agreed with. This research BRAC(13) also expressed the same opinion. Karim(15), Gill and Motahar(16) and Ali et al. ${ }^{(17)}$ identified the same as a major problem for fish culture. But the present study showed the major problem was lack of fund in flood-free zone and lack of training in both flooded zone and outside, which are not similar to their findings.

Three categories of ownerships were observed among the ponds and borrow pits in both inside and outside the embankment. The ownerships are the single, joint and leasetype. On the basis of ownership of closed water (both ponds and borrow pits), the highest production $(2,543$ and $2,606 \mathrm{~kg} / \mathrm{ha}$ ) was observed in lease ownership in inside the embankment (flood-free zone) during two years of study. The second highest (2,073 and $2046 \mathrm{~kg} / \mathrm{ha}$ ) was found in joint ownership ponds and borrow pits and the lowest production $(1,672$ and $1,724 \mathrm{~kg} / \mathrm{ha})$ was in single ownership ponds in inside region in 2003-2004 and 2004-2005, respectively. The highest fish production was 2,550 and 2,603 $\mathrm{kg} / \mathrm{ha}$ in single ownership ponds, the second highest was 2,297 and 2,189 kg/ha in lease ponds and the lowest production was 1,504 and $1,525 \mathrm{~kg} / \mathrm{ha}$ in joint ownership ponds in flooded zone of inside in 2003-2004 and 2004-2005, respectively. In case of outside ponds, 
the highest production was in lease ownership during both the years of study $(2,353$ and $2,355 \mathrm{~kg} / \mathrm{ha})$, followed by single ownership $(1,947$ and $1,994 \mathrm{~kg} / \mathrm{ha})$ and the lowest production was in joint ownership (1,586 and 1,583 kg/ha) in 2003-2004 and 2004-2005, respectively. The fish production in different ownerships is shown in Fig. 6. In both years of study, it was observed that the production was higher in lease ponds in the flood-free zone of inside the embankment, which was higher in single ownership in case of flooded zone and in lease ponds in outside region. The result also indicates that the single owner ponds and lease owner ponds are to be managed more or less scientifically than joint owner ponds.

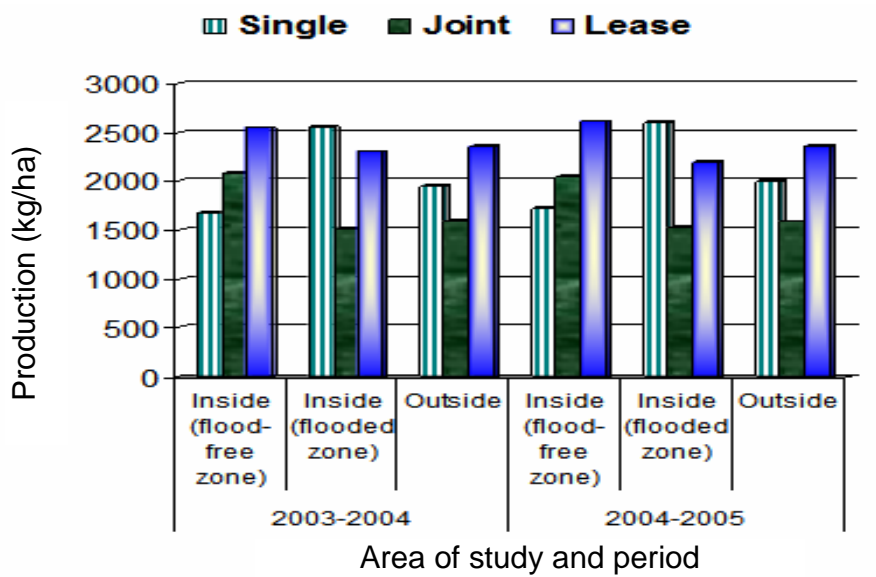

Fig. 6. Production of fishes in closed water (ponds and borrow-pits) on the basis of ownership both inside and outside of NNIP in 2003-2004 and 2004-2005.

During two years of study, two types of ponds, such as, seasonal and perennial were observed. In case of borrow pits, only perennial pond was observed. In the flood-free zone of inside the embankment, the production of fishes was 2,420 and 2,468 kg/ha in perennial water body (ponds and borrow pits) in 2003-2004 and 2004-2005, whereas 1,826 and $1,831 \mathrm{~kg} / \mathrm{ha}$ in seasonal water body. On the other hand, in the flooded zone of inside the embankment/regulator, the production was 2,366 and 2,399 kg/ha in perennial ponds but 1,330 and 1,328 $\mathrm{kg} / \mathrm{ha}$ in seasonal ponds in two years of study. In outside region, the production was 2,152 and 2,154 kg/ha in perennial ponds which was 1,316 and 1,370 $\mathrm{kg} / \mathrm{ha}$ in seasonal ponds in 2003-2004 and 2004-2005, respectively. It was evident that both inside and outside the embankment of NNIP, the production of fishes was higher in the perennial water body than the seasonal water body (Fig. 7). From the figure it is clear that the production of the closed water body (both seasonal and perennial) was higher in flood-free zone, followed by flooded zone and outside region in both years of study. 


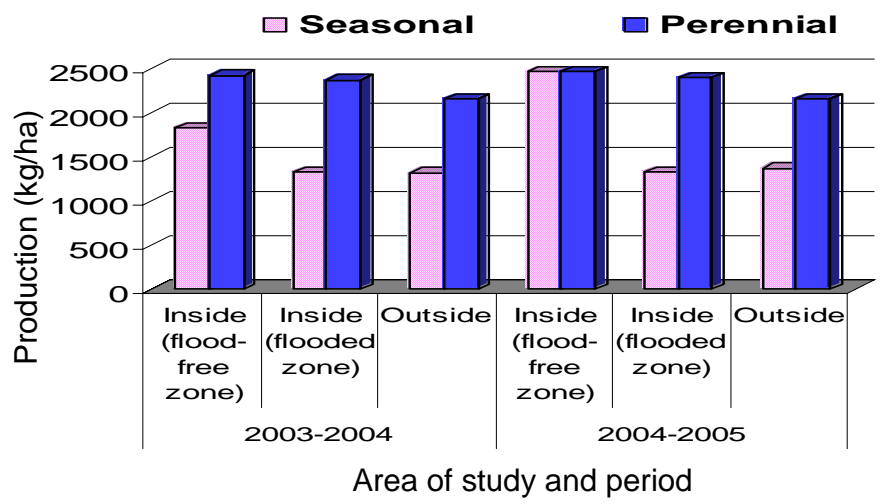

Fig. 7. Production of fishes in closed water (ponds and borrow-pits) on the basis of type of water body both inside and outside of NNIP in 2003-2004 and 2004-2005.

In 2003-2004 and 2004-2005, the production in cultured ponds and borrow pits was 2,373 and 2,416 kg/ha in the flood-free zone of inside, 2,219 and 2,254 kg/ha in flooded zone of inside and 2,130 and 2,133 kg/ha in outside. But in the culturable ponds, the production was lower (400 and $356 \mathrm{~kg} / \mathrm{ha}$ ) in the flood-free zone of inside, followed by flooded zone (950 and $917 \mathrm{~kg} / \mathrm{ha}$ ) than in outside region (959 and $942 \mathrm{~kg} / \mathrm{ha}$ ) in 2003-2004 and 2004-2005 respectively (Fig. 8). It was

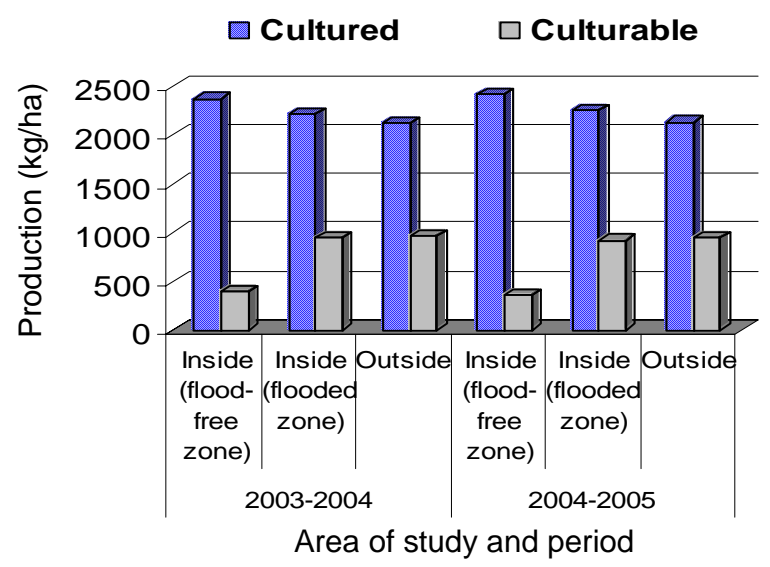

Fig. 8. Production of fishes in closed water (ponds and borrow-pits) on the basis of type of culture both inside and outside of NNIP in 2003-2004 and 2004-2005.

evident that the production of fishes in culturable ponds in outside region and in flooded zone of inside region was more than double than that of flood-free zone of inside the embankment (Fig. 8). But almost similar production was found in the culturable ponds of flooded zone and in the same ponds of outside region. In all cases, the production was always higher in cultured ponds and borrow pits than that of culturable ponds. 
In culturable ponds in flood-free zone of inside, the production was 400 and 356 $\mathrm{kg} / \mathrm{ha}$ in 2003-2004 and 2004-2005, which is less than the findings ofMPO(18). But the production of the same type of ponds in flooded zone in inside (950 and $916.67 \mathrm{~kg} / \mathrm{ha}$ ) and outside region (958.52 and $941.60 \mathrm{~kg} / \mathrm{ha}$ ) of NNIP in two years of study was similar which is almost double of the findings of $\mathrm{MPO}^{(18)}$.

It was observed that three types of methods of culture were practiced to culture fish in the ponds and borrow pits, such as, extensive, improved extensive and semi-intensive culture in both inside and outside region of NNIP. In the borrow-pits semi-intensive culture was not found. The highest production was in the semi-intensive ponds $(3,827$, 3,912 and $3800 \mathrm{~kg} / \mathrm{ha}$ ) in flood free-zone, flooded zone and outside respectively, followed by improved extensive culture $(2,673,2,356$ and 2,335 kg/ha) and the lowest production was in extensive culture $(1,756,1,603$ and 1,699 kg/ha) in 2003-2004. Similarly, the highest production was in semi- intensive culture $(3,980,4,000$ and 4,000 kg/ha) in flood- free zone, flooded zone and outside respectively followed by improved extensive culture $(2,694,2,261$ and $2,336 \mathrm{~kg} / \mathrm{ha})$ and the lowest production was in extensive culture (1798.50, 1,646 and 1,706 kg/ha) in 2004-2005. So, in all cases, it was revealed that the production of fishes was higher in semi-intensive culture, followed by improved extensive culture and the lowest production was in extensive culture (Fig. 9).

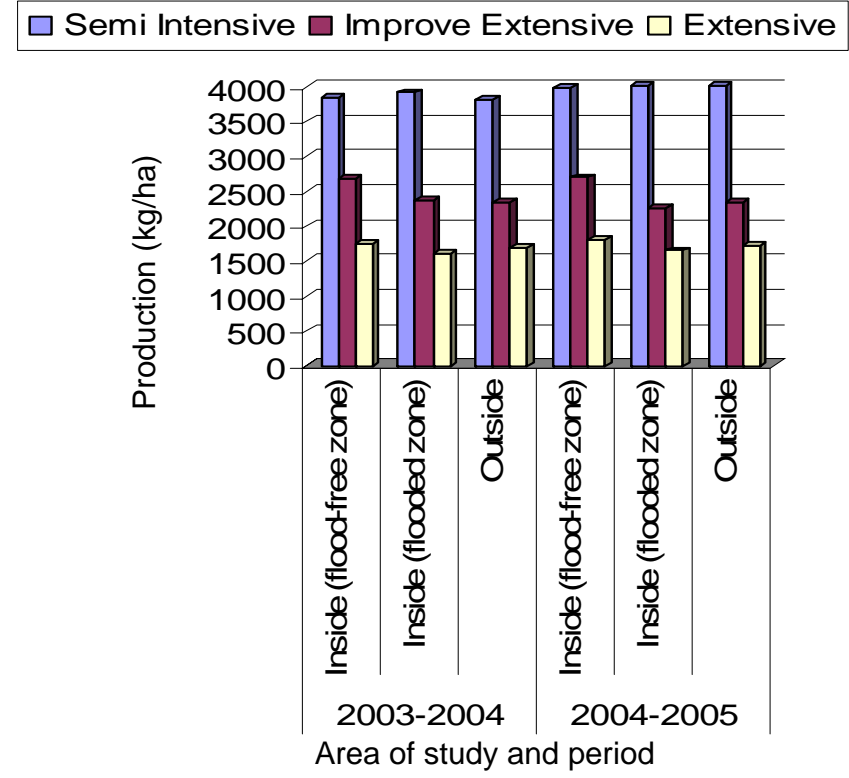

Fig. 9. Production of fishes in closed water (ponds and borrow-pits) on the basis of method of culture both inside and outside of NNIP in 2003-2004 and 2004-2005. 
Quddus et al.(19) found that per hectare yield of extensive, improved extensive and semi-intensive categories of culture were 1.3, 2.12 and $4.0 \mathrm{mt}$, respectively which supports the present findings of yield in extensive culture ponds (1.8, 1.6 and $1.7 \mathrm{mt} / \mathrm{ha})$, improved extensive culture ponds $(2.7,2.2$ and $2.3 \mathrm{mt} / \mathrm{ha})$ and semi-intensive culture ponds (3.98, 4.0 and $4.0 \mathrm{mt} / \mathrm{ha}$ ) in 2004-2005 in flood-free zone, flooded zone in inside and outside of NNIP.

The average production of fishes in closed water (ponds and borrow pits) in the flood-free zone of inside the embankment $(2,328$ and 2,368 kg/ha) was higher, followed by the production in flooded zone of inside the embankment/regulator $(2,249$ and 2,336 $\mathrm{kg} / \mathrm{ha})$ and the lowest average production was found in outside region (1,972 and 1,985 $\mathrm{kg} / \mathrm{ha}$ ) in 2003-2004 and 2004-2005, respectively (Fig. 10).

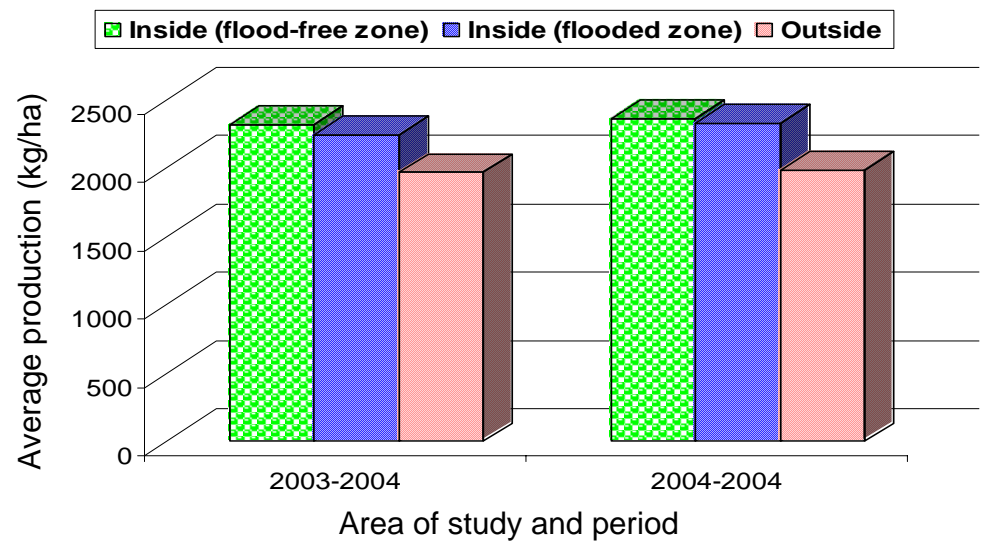

Fig. 10. Average production of fishes in ponds and borrow pits both inside and outside of NNIP in 2003-2004 and 2004-2005.

The average production was found 2,327 kg/ha in 2003-2004 and 2,368 kg/ha in floodfree zone in inside is slightly lower than the national average production of ponds $(2,609$ $\mathrm{kg} / \mathrm{ha})$ in 2003-2004 and (2,482 kg/ha) in 2004-2005. In contrast, the average production was found to be 2,249 and 2,336 kg/ha in flooded zone in inside and 1,972 and 1,985 $\mathrm{kg} / \mathrm{ha}$ in outside in 2003-2004 and 2004-2005 and is less than that of national average production in the same years ${ }^{(8,9)}$. The less production in flooded zone and outside might be the cause of over flooding of ponds in flooded zone and outside zone in NNIP.

\section{Acknowledgements}

This paper is a part of Ph.D. research work of the first author (MMH). He gratefully acknowledges the Ministry of Fisheries and Livestock, Govt. of Bangladesh, for granting deputation for the Ph. D. research work, and DFID and British Council for funding. 


\section{References}

1. DoF 2005. Brochure on Fish Fortnight. National Fish Fortnight-2005. Department of Fisheries, Ministry of Fisheries and Livestock, Dhaka, Bangladesh.

2. BBS 2001. Report of Household Income and Expenditure Survey 2001. Bangladesh Bureau of Statistics, Dhaka.

3. Rubbi SF, M Muslemuddin and MA Wahab 1978. The present status of fish technology and inspection in Bangladesh. Paper presented in FAO/ DANIDA Workshop of fish technology. Colombo, Srilanka.

4. Nilson. 1946. The value of fish and shellfish. Food Research. 30: 177-186.

5. BFRSS 1986. Manual of Catch Assessment Survey (Revised). DoF. MoFL. Dhaka. pp. 122.

6. CIRDAP 1987. The impact of FCD/I projects in Bangladesh: Benchmark Survey Initiation of a monitoring and evaluation system (MES). Final Report. FRC Entry No. 3185.

7. SPARRSO (Bangladesh Space Research and Remote Sensing Organization). 1984. Report on FAO/ UNDP Project in Bangladesh. Contract No. DP/ BGD/79/015-2/FI (Fisheries Resources Survey System). Dhaka. xiii + 120 pp.

8. BFRSS 2003-2004. Fishery Statistical Yearbook of Bangladesh. DoF. pp. 41.

9. BFRSS 2004-2005. Fishery Statistical Yearbook of Bangladesh. DoF. pp.42.

10. Kaiya MKU, MFA Mollah and MS Islam 1987. Survey of pond fishery resources in Mirzapur Upazila under Tangail district. Bangladesh J. Fish. 10(1): 37-43.

11. Rahman MM 1986. Small-scale fisheries in Bangladesh: Some socio-economic problems and issues. Bangladesh J. Agril. Econ. 9(2): 97-110.

12. Khan MS, MA Quddus and MA Islam 1991. A study of pond fishery resources in Trisal upazila. Bangladesh J. Ext. Edu. 6(1\&2): 55-64.

13. BRAC 1982. Inventory of Present Status of Fisheries Research in Bangladesh. Fisheries Technical Working Group, BRAC, Dhaka.

14. Haque KA 1980. Development and management of aquaculture. Paper presented as the seminar on Strategy for Aquaculture Development in Bangladesh, Bangladesh Agricultural University, Mymensingh, 4-5 Oct. 1980.

15. Karim M 1978. Status and Potential of Bangladesh Fisheries. Dacca: Ministry of Fisheries and Livestock. pp. 125.

16. Gill GJ and HA Motahar 1982. Social factors affecting prospects of intensified fish farming in Bangladesh. Bangladesh J. Agril. Econ. 5: 1-24.

17. Ali MH, MA Akbar and HM Rahman 1982. Utilization of fish ponds in Mymensingh district. Bangladesh J. Agril. Econ. 5: 103-114.

18. MPO 1984. Master Plan Organization. Water development and flood control, National Water Plan Project, Second Interim Report: VII Fishes. Dhaka, Ministry of Irrigation.

19. Quddus MA, MS Rahman and M Moniruzzaman 2000. Socio-economic conditions of the pond owners of Demra, Dhaka. Bangladesh J. Fish. Res. 4(2): 203-207. 